\title{
Unravelling safety compliance in the mining industry: examining the role of work stress, job insecurity, satisfaction and commitment as antecedents
}

\author{
Authors: \\ Uanda Masia ${ }^{1}$ \\ Jaco Pienaar ${ }^{2}$ \\ Affiliations: \\ ${ }^{1}$ Department of Industrial \\ Psychology, North-West \\ University, Potchefstroom \\ campus, South Africa \\ ${ }^{2}$ WorkWell: Research Unit for \\ Economic and Management \\ Sciences, North-West \\ University, Potchefstroom \\ campus, South Africa \\ Correspondence to: \\ Jaco Pienaar \\ Email: \\ Jaco.Pienaar@nwu.ac.za \\ Postal address: \\ Private Bag X6001, \\ Potchefstroom 2520, \\ South Africa \\ Dates: \\ Received: 14 Sept. 2010 \\ Accepted: 11 Aug. 2011 \\ Published: 11 Nov. 2011 \\ How to cite this article: \\ Masia, U., \& Pienaar, J. \\ (2011). Unravelling safety \\ compliance in the mining \\ industry: examining the role \\ of work stress, job insecurity, \\ satisfaction and commitment \\ as antecedents. SA Journal \\ of Industrial Psychology/SA \\ Tydskrif vir Bedryfsielkunde, \\ 37(1), Art. \#937, 10 pages. \\ http://dx.doi.org/10.1402/ \\ sajip.v37i1.937
}

(C) 2011. The Authors. Licensee: AOSIS OpenJournals. This work is licensed under the Creative Commons Attribution License.
Orientation: Safety compliance remains a major issue in the South African mining industry. This article explores the roles of specific work-related job and attitudinal variables in predicting compliance.

Research purpose: The objective of this study was to investigate the relationship of work stress, job insecurity, satisfaction and commitment to safety compliance in a mine.

Motivation for the study: The study aims to predict safety compliance through work-related variables in order to manage safety better.

Research design, approach and method: The researchers used a cross-sectional survey design with a convenience sample $(n=158)$. They distributed a survey booklet. It included a biographical questionnaire, scales for job insecurity, satisfaction, affective organisational commitment, workplace accidents and safety compliance as well as a work stress measure that comprised dimensions of role clarity, conflict and overload.

Main findings: The results showed that work stress and job insecurity had a negative relationship with safety compliance. The researchers found that only job satisfaction was a significant predictor of safety.

Practical/managerial implications: Although exploratory, this study suggests that promoting job satisfaction may improve safety compliance whilst job stress and job insecurity also relate negatively to safety compliance.

Contribution/value-add: This study shows that job satisfaction is more important than organisational commitment, job security and work stress for predicting safety compliance.

\section{Introduction}

The mining industry has been an important source of employment in South Africa since the early 1900s. Many men who left their homes to find employment in the mining industry never returned and many women, whose husbands moved to mining towns to find employment, became widows because of fatal mine accidents. This problem has a long history.

In the Witwatersrand gold mines, 15000 Black men died in work-related accidents between 1901 and 1939 (Smith, 1993). The industry has experienced a slight improvement in the fatality rate per annum. However, safety in the mines remains a concern. In 2003, 43 people lost their lives in the line of duty at Anglogold, whilst 27 people died at Anglo Platinum operations. In 2008, 34 and 29 people died in gold and platinum operations respectively (South Africa, 2004; 2008).

Mining in South Africa is still one of the toughest and most hazardous occupations (Paul \& Maiti, 2005). A strong focus on production characterises the mining industry. These high performance pressures and time constrains decrease the safety level of operations. Employees have strict targets to meet within specified timelines. They might encourage workers to take shortcuts and jeopardise safety. This has created problems for many employers in the mining industry, who are legally obliged to create and maintain a safe working environment for all employees (Ashworth \& Peake, 1994; Janssens, Brett \& Smith, 1995; Probst \& Brubaker, 2001; South Africa, 1996).

In response to the tension between production and safety compliance, the National Union of Mine Workers (NUM) declared a one-day strike on 02 November 2007 in protest against 'death 
in the line of duty' in mines (The Star, 2007). This aligns with the requirements of the Mine Health and Safety Act 29 of 1996 (South Africa, 1996) that obliges employers to provide a safe and healthy working environment for all employees, including contractors.

Most researchers found the safety record of mines in South Africa unacceptable (Ashworth \& Peake, 1994; Bezuidenhout, 1992; Ferguson, 2000; Fourie, 1974; Gardner, 1998; Moller, 2003; Smith, 1993; South Africa, 2006; The Star, 2007; Van Wyk \& De Villiers, 2008). Given these findings, one needs to address the dearth of research in this area.

Therefore, the main objective of this investigation was to investigate safety compliance in the mining industry in South Africa. To reach this goal, the researchers studied safety compliance within a work stress-framework of organisational antecedents and outcomes.

\section{Background to the study}

Most researchers believe that there are circumstances that relate indirectly to accidents. Therefore, it is necessary to conduct an in-depth analysis of the underlying causes of accidents in order to draw relevant or usable conclusions.

Simpson and Widdas (1992) believe that certain features inherent in the mining system lead to slips, lapses, mistakes or violations that result in serious consequences - mostly accidents. Human failing or error cause most accidents (Hoffmann, Jacobs \& Landy, 1995; Lawrence, 1974; Raath, 1993). Ashworth and Peake (1994) suggest that the harsh physical conditions experienced in the mining industry could exacerbate this perception of human error as a causal factor in mining accidents in South Africa.

Companies are striving to improve production. In the process, employees are overlooking safety procedures whilst attempting to reach performance targets (Fourie, 1974; Moller, 2003; Probst \& Brubaker, 2001). Because of performance pressure and time constraints, many workers could engage in unsafe behaviours. They include short cuts that compromise safety compliance and can cause accidents.

Findings generally show that safety compliance decreases in proportion to increased work stress (Dawson, 1991; Hofmann, Jacobs \& Landy, 1995; Hofmann \& Stetzer, 1998; Janssens, Brett \& Smith, 1995; Kotze, 2005).

Ferguson (2000) suggests that the role of the individual in the mining industry needs further exploration. Ashworth and Peake (1994) also emphasise this. They believe that investigators should record and consider overloaded employees' responsibilities, impractical job requirements and lapses in concentration during accident investigations. Specifically, Clarke (2010) calls for more research on the direct relationship between psychological climate (the workers' experience of organisational policies, practices and procedures) and safety behaviour.
The authoritarian management styles and an uncaring attitudes that mineworkers experience from their managers, coupled with the strong focus on production, also contribute to employees' job insecurity (Ashworth \& Peake, 1994; Moller, 2003; Paul \& Maiti, 2005). These factors tend to draw employees' focus from safety requirements and contribute to workplace accidents and incidents (Ashworth \& Peake, 1994; Janssens, Brett \& Smith, 1995; Moller, 2003; Paul \& Maiti, 2005; Probst \& Brubaker, 2001; Smith, 1993).

\section{Trends from the literature Work stress}

According to Kreitner and Kinicki (2004), stress is:

an adaptive response, mediated by individual characteristics and/or psychological processes, that is a consequence of any external action, situation, or event that places special physical and/or psychological demands upon a person.

(Kreitner and Kinicki 2004, p. 692)

A combination of role conflict, role overload and role ambiguity indicates work stress (DeFrank \& Ivancevich, 1998; Nelson \& Burke, 2000; Newstorm \& Davis, 2002; Rothmann \& Malan, 2006).

Role conflict occurs when the different role setters have inconsistent and conflicting expectations of the focal person. People in role conflicting situations might fail to comply with role demands (Travers \& Cooper, 1996). Role overload is the degree to which inadequate time, training and resources affect performance.

When the role setters' expectations exceed the focal person's ability, the focal person might experience stress (Jones, 1979; Kreitner \& Kinicki, 2004). Role ambiguity, also called a lack of role clarity, occurs when the role setters' expectations are unknown and the focal person does not have the information needed to perform the role. Prolonged role ambiguity can increase work stress and job dissatisfaction (Khan \& Cooper, 1993; Kreitner \& Kinicki, 2004).

Job-related stress has a negative effect on professional work and personal welfare. This includes low organisational commitment, low job satisfaction and a higher incidence of workplace accidents (Ashworth \& Peake, 1994; Gillespie et al., 2001; Hofmann \& Stetzer, 1998; Kendonlin, 1993; Kotze, 2005; Monk \& Folkard, 1985; Paul \& Maiti, 2005). Alper and Karsh (2009) show that variables like time pressure and conflicting demands have relationships with safety violations. These variables are clearly conceptually similar to the role stressors mentioned earlier. In this conceptualisation of stress, it is clear that there is a direct relationship with safety compliance.

\section{Job insecurity}

According to Hellgren, Sverke \& Isaksson (1999) job insecurity:

- is subjective and therefore workers will react differently although they are exposed to similar situations 
- implies uncertainty about the future

- includes doubts about continued employment.

Hellgren et al. (1999) used the term 'quantitative' job insecurity to refer to concerns about the future of the current job and 'qualitative' job insecurity to refer to perceived threats of reduced quality in the employment relationship (relating to aspects like career progression and salary increases).

Researchers have found that job insecurity relates negatively to employees' work attitudes, to employee wellbeing (Ashford, Lee \& Bobko, 1989; Dekker \& Schaufeli, 1995; De Witte, 1999; Hellgren et al., 1999; Probst \& Brubaker, 2001) and to psychological health (Dekker \& Schaufeli, 1995). Experiencing job insecurity over time also predicts and produces impaired job and organisational attitudes. Organisational attitudes include, but are not limited to, intentions to leave, organisational commitment and job satisfaction (Hellgren et al., 1997; Probst \& Brubaker, 2001). Most researchers found that job insecurity has a relationship with a reduced level of intrinsic and extrinsic job satisfaction as well as with decreased workplace opportunities for growth and promotion (Ashford et al., 1989; Dekker \& Schaufeli, 1995; De Witte, 1999; Hellgren et al., 1999; Probst \& Brubaker, 2001).

The strong and increasing focus on production, deadlines for reaching targets and workplace accidents contribute to a climate of insecurity, if not to actual job losses and retrenchments. This has fuelled a considerable amount of fear about job loss, especially amongst employees at lower levels (Gardner, 1998; Marx, 1996; Odendaal, 1996; Smith, 1993). In addition, job insecurity, dissatisfaction and unsafe behaviours are related (Probst \& Brubaker, 2001; Rundmo \& Iversen, 2007). Therefore, job insecurity is a major concern in the mining industry.

\section{Job satisfaction}

Hellgren, Sjöberg and Sverke (1997, based on Brayfield \& Rothe, 1951) define job satisfaction as a positive emotional state that reflects affective reactions to the perceived content and characteristics of specific facets of the job situation. Both organisational and dispositional factors influence it. Job satisfaction is often an indicator of organisational effectiveness (Hirschfield, 2000; Kreitner \& Kinicki, 2004; Spector, 1997). Job satisfaction has a negative relationship with job insecurity and work stress. Meanwhile, employees with high levels of job satisfaction also experience and exhibit high levels of organisational commitment (Kotze, 2005; Paul \& Maiti, 2005; Probst \& Brubaker, 2001; Ramakau, 2006).

A negative consequence of employee job dissatisfaction could be allowing conditions to worsen - including reduced effort and increased error rate - thereby leading to increased incident rates (Probst \& Brubaker, 2001).

Job insecurity and dissatisfaction also have a negative relationship with using personal protective equipment (Dunbar, 1993). This could, in turn, have a negative effect on employee safety compliance and increase the number of workplace accidents and incidents. Employee satisfaction increases profits, reduces grievances and decreases incident rates (Dunbar, 1993; Probst \& Brubaker, 2001; Robbins, 1998; Rossouw \& Bews, 2002). However, satisfaction and commitment do not mediate the relationship between perceptions of the safety climate in organisations and safety behaviour (Larsson, Pousette \& Törner, 2008). Clearly, satisfaction is an important dimension to consider when studying workplace safety because of its strong negative relationships with aspects like insecurity and a lack of commitment.

\section{Organisational commitment}

Organisational commitment is the psychological link between employees and their organisations. It reduces the likelihood that employees will leave their organisations voluntarily (Allen \& Meyer, 1990). It is the relative strength of the employees' identification and interaction with their organisations. Affective organisational commitment is more relevant and has profitable outcomes for organisational functioning when compared to continuance commitment (perceived costs associated with leaving an organisation) and normative commitment (obligations to remain with an organisation) (Allen \& Meyer, 1990; Buitendach \& De Witte, 2005; Coleman, Irving \& Cooper, 1999).

Commitment has a positive effect on compliance with organisations' rules, regulations and policies. It also implies a positive effect on safety compliance. Clarke (2010) also showed a direct relationship between commitment and the organisations' safety climate. Committed employees identify with organisations and commit to their goals (Ramakau, 2006). Employees who experience job insecurity and high workplace stress levels experience lower levels of organisational commitment (Paul \& Maiti, 2005; Probst \& Brubaker, 2001). Meanwhile, employees who are highly satisfied with their jobs have high levels of organisational commitment (Kotze, 2005; Paul \& Maiti, 2005; Probst \& Brubaker, 2001).

Given the relationships between the variables of interest in this study, it is reasonable to conclude that employees who are committed to their organisations will also exhibit high levels of commitment to safety practices.

\section{Safety compliance}

Safety compliance is the extent to which employees adhere to safety standards, procedures, legal obligations and requirements. It is also an absence of accidents and incidents in the workplace (Adams, Du Plessis, Gumbie \& Willis, 2007; Neal, Griffin \& Hart, 2000; Stanton, Kielblock, Schoeman \& Johnston, 2007). There are other significant organisational factors that encourage unsafe acts and lead to workplace accidents. They include, amongst others, the harsh conditions of the mining industry (Ashworth \& Peake, 1994; Hoffmann et al., 1995; Kletz, 1985; Zohar, 1980). 
Unsafe behaviour triggers between $80 \%$ and $95 \%$ of all workplace accidents and human error often gets the blame (Ashworth \& Peake, 1994; Paul \& Maiti, 2005). This suggests that addressing the relationship between the workplace environment and employees as individuals may increase safety compliance (Ashworth \& Peake, 1994; Cooper, 1999a; Ferguson, 2000; Lawrence, 1974; Moller, 2003). Issues like job insecurity and work stress affect employee safety compliance negatively (Ashford et al., 1989; Ashworth \& Peake, 1994; Dawson, 1991; Dollard, Winefield \& Winefield, 1993; Hofmann \& Stetzer, 1998; Paul \& Maiti, 2005; Probst \& Brubaker, 2001; Moller, 2003). On the other hand, concepts like organisational commitment and job satisfaction have a positive relationship with employee safety compliance (Ashworth \& Peake, 1994; Paul \& Maiti, 2005; Probst \& Brubaker, 2001).

\section{Potential value of the study and research objectives}

The diagram that follows describes the inter-relationship between work stress, job insecurity, organisational commitment, job satisfaction and organisational commitment best.

The objective of this study is to investigate the relationship between work stress, job insecurity, organisational commitment, job satisfaction and safety compliance in a mine and to determine whether one can use work-related variables and attitudes to predict the safety compliance of employees.

The rest of this article presents the results of an exploratory investigation into the roles that the job-related experience of work stress and job insecurity as well as individual attitudinal factors, in the form of job satisfaction and affective commitment, play in predicting safety compliance.

\section{Research design \\ Research approach}

The researchers used a cross-sectional research design. They drew a sample from the population of employees in a mining organisation between June and August 2009. Cross-sectional designs assess inter-relationships between variables in a population that one observes at a specific point in time (Shaughnessy \& Zechmeister, 1997). This design is well suited for addressing the descriptive and predictive functions of correlational research.

\section{Research method}

\section{Research participants}

The researchers invited employees from the ranks of miner to production manager $(n=300)$ to participate. They received 158 questionnaires. This is a response rate of $52.67 \%$. Table 1 gives an indication of the characteristics of the participants in this study.

Most participants were men (95.6\%). Most participants $(46.2 \%)$ had a grade 12 qualification, $3.8 \%$ held a national diploma and $8.2 \%$ had a blasting certificate. Most participants (50.6\%) were shift supervisors. The second largest group ( $40.5 \%$ ) were miners, whilst only $0.6 \%$ were section managers. All participants were permanent, full-time employees and $83.5 \%$ of the participants were union members. The average number of years in their occupation was 8.47 years.

\section{Measuring instruments}

All the scales were embedded in a survey, with items randomly presented. The survey included the scales that follow.

The researchers used the Job Insecurity scales of Hellgren, Sverke and Isaksson (1999) to measure qualitative and quantitative job insecurity. The questionnaire consists of seven items (three qualitative and four quantitative) on a fivepoint scale. The scale ranged from 1 ('strongly disagree') to 5 ('strongly agree'). A typical item that measured qualitative job insecurity is 'I think my future prospects within this company are good', whilst a typical item for quantitative job insecurity is 'I am afraid I might lose my job'.

The reliability of the scale, indicated by Chronbach's alpha coefficients as reflected in test-retest correlations, ranged from 0.51 to 0.68 (Hellgren et al., 1999). Previous South African research (Fourie, 2005) has shown that this scale is reliable locally. It yielded reliability coefficients of 0.75 and 0.82 for qualitative and quantitative job insecurity respectively.

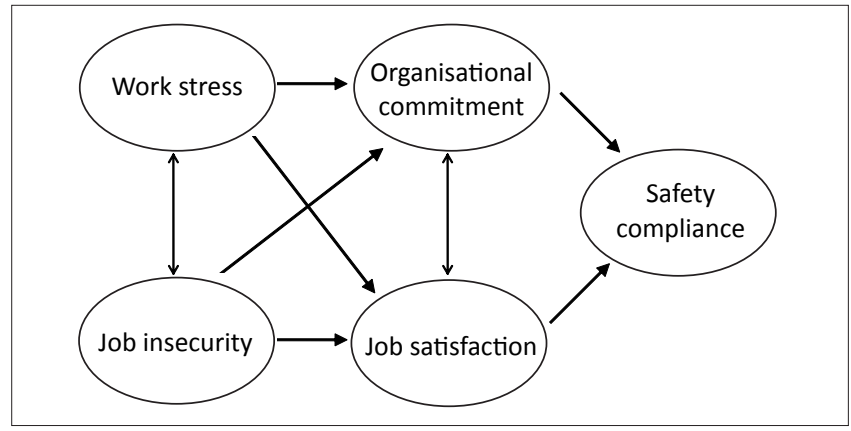

FIGURE 1: A conceptual model of the relationship between work stress and job insecurity with workplace safety compliance, job satisfaction and commitment.

TABLE 1: Demographic characteristics of participants ( $n=158)$.

\begin{tabular}{llcc}
\hline Item & Category & Frequency & $\mathbf{\%}$ \\
\hline Gender & Female & 4 & 2.5 \\
& Male & 151 & 95.6 \\
& Primary & 3 & 1.9 \\
& Secondary & 44 & 27.8 \\
& Grade 12 & 73 & 46.2 \\
& College & 11 & 7.0 \\
& National diploma & 6 & 3.8 \\
& University degree & 8 & 5.1 \\
& Other & 13 & 8.2 \\
Employment level & Miner & 64 & 40.5 \\
& Shift supervisor & 80 & 50.6 \\
& Mine overseer & 9 & 5.7 \\
& Section manager & 1 & 0.6 \\
& Production manager & 2 & 1.3 \\
Union membership & Yes & 132 & 83.5 \\
& No & 25 & 15.8 \\
\hline
\end{tabular}

Note: Percentages that do not add to 100 are the result of missing values. 
The Job Satisfaction questionnaire of Hellgren, Sjöberg and Sverke (1997, based on Brayfield \& Rothe, 1951) consists of three items measured on a five-point scale that ranges from 1 ('strongly disagree') to 5 ('strongly agree'). A typical item that measures job satisfaction is 'I am satisfied with my job'. Chronbach's Alpha coefficients ranged from 0.80 to 0.95 (Brayfield \& Rothe, 1951; Pienaar et al., 2007), which is an indication of the reliability of the scale.

The researchers used the Affective Organisational Commitment Questionnaire of Allen and Meyer (1990, short-form version) to measure affective organisational commitment. The questionnaire consists of four items on a five-point scale that ranges from 1 ('strongly disagree') to 5 ('strongly agree'). An example of an item in this questionnaire is 'I often feel like the organisation's problems are the same as my own problems'. Chronbach's Alpha coefficients for the total score show the reliability of this scale. They were above 0.70 (Allen \& Meyer, 1990).

The researchers used the Workplace Accidents and Safety Compliance questionnaire of Probst and Brubaker (2001) to measure safety compliance. The questionnaire consists of four questions. One question used a five-point scale that ranges from 1 ('never') to 5 ('always'). The other three items are open-ended and require participants to record a number. An example of an item in this questionnaire is 'How many work related accidents have you reported in the past 12 months?' On the first item, respondents are asked to indicate how often they ignore safety rules and regulations at work ('never' to 'always'). Neal and Griffin (2006) have reported a link between self-reported safety behaviour data and accidents.

It is important to note that one scores the safety compliance scale in the opposite direction to the others. A high score on this scale indicates that the measured variable is absent (a high score on the safety compliance item shows no compliance). The researchers reversed scores on the scale to facilitate interpretation. Therefore, a high score on safety compliance shows high levels of safety compliance. Work stress consists of role clarity, role conflict and role overload.

Role clarity has four items that are a combination of items from Rizzo, House and Lirtzman (1970) and Caplan (1971). The items use a five-point scale that ranges from 1 ('strongly disagree') to 5 ('strongly agree'). A typical item that measures role clarity is 'I know what my responsibilities are'. A Chronbach's alpha, which ranges from 0.78 to 0.81 , shows the reliability of this scale (Rizzo, et al, 1970).

Five items from the Rizzo et al. (1970) scale measured role conflict. The items use a five-point scale that ranges from 1 ('strongly disagree') to 5 ('strongly agree'). An example of an item on this scale is 'I have to buck a rule or policy in order to carry out a work assignment'. Rizzo et al. (1970) found a Chronbach's alpha of above 0.80 , which is an indication of the reliability of this scale.
Quantitative role overload (Beehr, Walsh \& Taber, 1976) has three items that use a five-point scale that ranges from 1 ('strongly disagree') to 5 ('strongly agree'). A typical item on this questionnaire is 'I often have too much to do in my job'. Chronbach's alpha for this scale ranges between 0.56 and 0.81 (Beehr et al., 1976; Pienaar et al., 2007; Näswall et al., 2006). This shows that the reliability of this scale is not always consistent.

Qualitative role overload (Sverke et al., 1999) has four items that use a five-point scale that ranges from 1 ('strongly disagree') to 5 ('strongly agree'). A typical item that measures qualitative role overload is 'I feel unreasonable demands in my work'. A Chronbach's alpha that ranges from 0.74 to 0.79 shows the reliability of this scale (Pienaar et al., 2007; Sverke, Hellgren \& Öhrming, 1999).

\section{Research procedure}

The relevant faculty committee in the institution granted ethical clearance for the study. The primary researcher was a post-graduate student at the institution. The researchers made appointments with the production managers in order to access their staff and distributed questionnaires to prospective participants. The researchers included a letter requesting participation in the survey and an explanation of the ethical aspects (informed consent, free participation and withdrawal) as well as a motivation about the importance of the research. They handed out questionnaires during safety meetings. They placed respondents' boxes in each change house at the shaft and the primary researcher delivered them personally. Some participants preferred to deliver completed questionnaires by hand. Each team was given four weeks in which to complete the questionnaire and return it.

\section{Statistical analysis}

The researchers used the SPSS programme (SPSS, 2009) to conduct the statistical analyses. They determined the construct validity of the measuring instruments using exploratory factor analysis. They used Chronbach alpha coefficients to determine reliability. They used Pearson product moment correlation coefficients to specify the relationship between variables. They set a $95 \%$ confidence level ( $p \leq 0.05)$ for statistical significance and a cut-off point of 0.30 to determine the practical significance of the correlation coefficients (Cohen, 1988).

The researchers conducted stepped logistic regression to clarify the contribution of work-related attitudes and experiences (work stress, job insecurity, job satisfaction and commitment) to the participants' adherence to safety regulations. This stepped procedure can choose a subset that provides the best predictive power from a group of potential predictors. Logistic regression assesses the 'goodness of fit' and provides an indication of the adequacy of a research model (set of predictor variables). This allows researchers to assess how well the set of predictor variables predict the dependant variable (Pallant, 2007). 


\section{Results}

Many of the scales the researchers used here have not been used in the South African context previously or there is limited evidence of their reliability in the South African context. Therefore, the first focus was to investigate the reliability of the different scales. Most of these scales have proven reliable in previous international research (Näswall et al., 2006). Results show that the Chronbach alpha values the researchers obtained for the measuring instruments of job satisfaction were acceptable. However, they adjusted work stress, affective organisational commitment and job insecurity to improve reliability.

The work stress variable comprises items for goal clarity, role overload and role conflict. The researchers found a Chronbach alpha coefficient of 0.70 for role conflict, 0.70 for qualitative role overload and 0.30 for quantitative role overload.

The researchers combined qualitative and quantitative role overload to create a total role overload variable. They then found that the Chronbach alpha coefficient for the collapsed scale was 0.72 . However, when they investigated the reliability of the goal clarity scale, it yielded a Chronbach alpha coefficient of only 0.58 . They deleted the third item on the scale to improve the Chronbach alpha to 0.73. Finally, they decided to combine all items to create a total work stress measure. Here, the Chronbach alpha was 0.71.

The researchers found that the Chronbach alpha for job satisfaction was 0.75 and 0.60 for affective organisational commitment. They deleted the first item on the commitment scale to improve the Chronbach alpha to 0.70 . They found that the Chronbach alphas for qualitative job insecurity were 0.40 and 0.78 for quantitative job insecurity respectively. They then combined qualitative and quantitative job insecurity to measure total job insecurity and deleted another item (from the quantitative scale) to improve the Chronbach alpha coefficient to 0.70 . Table 2 gives the descriptive statistics for the different variables.
Table 2 shows that all the adjusted measuring instruments have acceptable levels of internal consistency. All the alpha coefficients were equal to or greater than 0.70 (Nunnally \& Bernstein, 1994). A single item represents safety compliance and therefore no reliability information is available. All scales have normal distributions (as shown by skewness and kurtosis) except for safety compliance. This is positively skewed (most respondents indicated that they were 'compliant').

Table 3 below gives the correlations between the different variables. The researchers used Pearson product moment correlation coefficients to specify the relationships between all variables. Only a single item assesses safety compliance. Therefore, the researchers computed Spearman-rank correlations for this because it is a more restrictive procedure than Pearson's correlation.

Table 3 shows that work stress is statistically significant and relates directly to job insecurity (practically significant, large effect) and inversely to safety compliance (statistically significant, small effect). Job insecurity is statistically significant and relates inversely to safety compliance. Job satisfaction relates directly to affective commitment (practically significant, large effect). Work stress, job insecurity and safety compliance did not show statistically significant relationships with job satisfaction or organisational commitment.

In the next phase of the analysis, the researchers performed a stepped logistic regression to clarify the contribution of work-related attitudes and experiences (work stress, job insecurity, job satisfaction and commitment) to participants' indications of whether they adhere to safety regulations or not. In logistic regression, the dependent variable (in this case, safety compliance) transforms to a dichotomous variable ('safety compliant' $[n=87]$ vs. 'noncompliant' $[n=66])$ to classify cases that do and do not exhibit the variable of interest. The researchers recoded the participants, who indicated anything other than 'always' in terms of being compliant, as 'non-compliant'. Table 4 presents the results of this regression.

TABLE 2: Descriptive statistics and Chronbach Alpha Coefficients of the measuring instruments.

\begin{tabular}{|c|c|c|c|c|c|}
\hline Item & Mean & SD & Skewness & Kurtosis & $\alpha$ \\
\hline Work stress & 2.97 & 0.84 & -0.06 & -0.16 & 0.71 \\
\hline Job insecurity & 3.11 & 0.97 & -0.42 & -0.52 & 0.70 \\
\hline Safety compliance & 1.90 & 1.31 & $1.39^{\mathrm{a}}$ & 0.66 & b \\
\hline Job satisfaction & 3.99 & 0.90 & -0.80 & 0.23 & 0.75 \\
\hline Organisational commitment & 3.79 & 0.79 & -0.74 & 0.70 & 0.70 \\
\hline
\end{tabular}

SD; Standard deviation; $\alpha$, Cronbach alpha.

a, high skewness.

b', using a single item prohibits determining an alpha coefficient for this scale.

TABLE 3: Correlation coefficients between work stress, job insecurity, job satisfaction, organisational commitment and safety compliance.

\begin{tabular}{|c|c|c|c|c|}
\hline Variables & Work stress & Job insecurity & Safety compliance & Job satisfaction \\
\hline Work stress & - & - & - & - \\
\hline Job insecurity & $0.55 \dagger$ & - & - & - \\
\hline Safety compliance & $-0.22 \dagger$ & $-0.21 \ddagger$ & - & - \\
\hline Job satisfaction & -0.14 & -0.04 & -0.03 & - \\
\hline Organisational commitment & 0.13 & 0.05 & -0.11 & $0.52 \dagger$ \\
\hline
\end{tabular}


TABLE 4: Logistic regression predicting the likelihood of reporting safety compliance.

\begin{tabular}{|c|c|c|c|c|c|c|c|c|}
\hline \multirow[t]{2}{*}{ Variables } & \multirow[t]{2}{*}{ Beta-values } & \multirow[t]{2}{*}{ SE } & \multirow[t]{2}{*}{ Wald } & \multirow[t]{2}{*}{$d f$} & \multirow[t]{2}{*}{$p$} & \multirow[t]{2}{*}{ Odds ratio } & \multicolumn{2}{|c|}{$95 \%$ confidence level for odds ratio } \\
\hline & & & & & & & Lower & Upper \\
\hline Age & -0.033 & 0.027 & 1.510 & 1 & 0.219 & 0.967 & 0.918 & 1.020 \\
\hline Level of education & 0.216 & 0.147 & 2.151 & 1 & 0.142 & 1.241 & 0.930 & 1.657 \\
\hline Type of employment & 0.222 & 0.302 & 0.543 & 1 & 0.461 & 1.249 & 0.691 & 2.256 \\
\hline Job insecurity & -0.105 & 0.264 & 0.160 & 1 & 0.689 & 0.900 & 0.537 & 1.509 \\
\hline Work stress & -0.708 & 0.481 & 2.166 & 1 & 0.141 & 0.493 & 0.192 & 1.265 \\
\hline Job satisfaction & 0.806 & 0.308 & 6.835 & 1 & 0.009 & 2.239 & 1.224 & 4.097 \\
\hline Organisational commitment & -0.176 & 0.359 & 0.239 & 1 & 0.625 & 0.839 & 0.415 & 1.697 \\
\hline Constant & 0.771 & 1.827 & 0.178 & 1 & 0.673 & 2.163 & - & - \\
\hline
\end{tabular}

$\mathrm{SE}$, standard error; $d f$, degrees of freedom; $p$, probability value.

The baseline model showed that the researchers could classify $59.2 \%$ of the sample. In other words, they estimated that $59.2 \%$ of the sample would indicate that they are safety compliant, but only because a higher percentage of respondents actually indicated that they are.

Testing the model with the first set of independent variables (age, level of education and type of employment) included yielded statistical significance only at the $p \leq 0.10$ level $\left(\chi^{2}=6.16 ; d f=3\right)$.

The Hosmer-Lemeshow Test showed a non-significant value $\left(\chi^{2}=10.10 ; p=0.26\right)$. This supports the model. The researchers examined the Cox and Snell $R^{2}$ and the Nagelkerke $R^{2}$. We call these 'pseudo $R^{2}$ statistics' (Pallant, 2007, p. 174). They saw that the model unfortunately only explains between $5 \%$ and $6.7 \%$ of the variance, which is rather low. This model correctly classified only $57.5 \%$ of cases.

In the second step of the regression, the researchers added the work-related variables of work stress, job insecurity, job satisfaction and organisational commitment. This model was statistically significant $(p=0.01)$. The Cox and Snell $R^{2}$ and the Nagelkerke $R^{2}$ now showed that the model explained significantly more variance (between $14.5 \%$ and $19.6 \%$ of the variance). The Hosmer-Lemeshow Test yielded a nonsignificant value $\left(\chi^{2}=6.14 ; p=0.63\right)$. This still supports the model. For this model, the percentage accuracy in classification rose to $64.2 \%$. This is a little better than that of the baseline model (59.2\%).

Table 4 shows that, of all the independent variables, only job satisfaction made a statistically significant contribution to predicting safety compliance $(p \leq 0.05)$. The odds ratio shows that if people are satisfied with their jobs, they are 2.24 times more likely to be safety compliant than people who are not satisfied with their jobs.

\section{Discussion}

The mining sector in South Africa is a significant contributor to the national economy and the effect of safety in this context is crucial. However, little empirical work seems to take place or is published about it. The main aim of this research was to investigate workplace safety compliance in a South African mine. The researchers achieved this by focussing on the relationships between work stress, job insecurity, job satisfaction, organisational commitment and workplace safety compliance.

When the investigation focused on the relationships between work stress, insecurity and safety compliance, the researchers found a strong and direct relationship between stress and insecurity. Job insecurity is a work stressor. It is a type of stress mainly related to doubts about continued employment (Ashford, Lee \& Bobko, 1989; Lim, 1997; Greenhalgh \& Rosenblatt, 1984; Matteson \& Ivancevich, 1987). Therefore, this finding is consistent with international literature.

Both stress and insecurity had inverse relationships with safety compliance. This indicates that higher levels of stress and more insecurity should affect safety compliance negatively. The inverse relationship confirms previous research (Ashford et al., 1989; Ashworth \& Peake, 1994; Dawson, 1991; Hofmann, Jacobs \& Landy, 1995; Hofmann \& Stetzer, 1998; Janssens, Brett \& Smith, 1995; Kotze, 2005; Paul \& Maiti, 2005; Probst \& Brubaker, 2001). However, it also contradicts Clarke's recent meta-analysis (Clarke, 2010): that role perceptions and safety behaviour were unrelated. In addition, Emberland and Rundmo (2010) show no relationship between different dimensions of job insecurity and risk behaviour.

Empirical results about the idea that 'safety climate' (Zohar, 1980; 2010) mediates the relationship between individual organisational experience (psychological climate) and individual organisation related attitudes, like satisfaction and commitment, are not equivocal. There is some evidence that there is a full mediating effect (Barling et al., 2002; Wallace et al., 2006). Other research supports only a partial mediating effect (Clarke, 2010). Although the current researchers did not measure safety climate as such, their finding that work stress and insecurity have a significant relationship with safety compliance implies that there is certainly no full mediating effect.

This investigation found a strong and direct relationship between satisfaction and commitment. This is consistent with previous research (Kotze, 2005; Paul \& Maiti, 2005; Probst \& Brubaker, 2001; Ramakau, 2006). The researchers found that both had an inverse but insignificant relationship with work stress and insecurity. This supports previous findings (Paul \& Maiti, 2005; Probst \& Brubaker, 2001). Contrary to previous findings (Dunbar, 1993; Probst \& Brubaker, 2001; Ramakau, 
2006; Robbins, 1998; Rossouw \& Bews, 2002), satisfaction and commitment did not have significant correlational relationships with safety compliance. This again supports the findings of Clarke (2010). It is interesting to note here that the work-related experiences of insecurity and stress relate to safety compliance, whilst none of the attitudinal variables (satisfaction and commitment) had statistically significant relationships with safety compliance ${ }^{1}$.

Post hoc hypotheses are, of course, speculative and may easily seem to be presumptuous. However, the precarious employment situation in large sections of the South African economy, and especially in the mining industry, may be relevant. Employees may consider issues like insecurity and stress in their decisions about safety compliance rather than personal satisfaction or commitment. Insecure and unhealthy employment that still yields an income may easily outweigh personal satisfaction or loyalty to the employer. The tension between productivity and safety is well known (Zohar, 2000; 2010). The mining environment is especially vulnerable, with its product closely linked to fluctuating exchange rates and a volatile global economy. The literature on safety violations is informative here. It indicates that not all violations necessarily result in negative outcomes (see Alper \& Karsh, 2009).

The final step of the current investigation sought to clarify whether work-related attitudes and experiences (work stress, job insecurity, job satisfaction and commitment) contributed to the participants' assertions that they adhere to safety regulations or not. The findings show that job satisfaction is the best predictor of safety compliance. This suggests that employees, who are satisfied with their jobs, are more likely to be safety compliant. Therefore, one can argue that an increase in job satisfaction may bring about an increase in safety compliance. This confirms the findings of earlier studies (Ashworth \& Peake, 1994; Paul \& Maiti, 2005; Probst \& Brubaker, 2001).

\section{Limitations of the research}

There are limiting contextual factors that one needs to consider when interpreting these results. The researchers collected the data during a time of great uncertainty in the mining industry. For example, one of the participating mining organisation's operations had two separate entities. This had a direct effect on the job insecurity of employees. The later worldwide economic downturn also had a direct effect on employees' work stress and job insecurity.

Furthermore, the convenience sample did not represent the workforce of the entire organisation. Systematic sampling error may have played a role because the employees who are safety compliant may have considered it important to participate in the survey. However, when the researchers recoded them into compliant and noncompliant employees, the distribution did represent both categories. One can also not

1.One has to acknowledge, as an anonymous reviewer pointed out, that safety compliance was a continuous variable in the correlations whilst it was a dichotomous variable in the logistic regression. discount the role of social desirability. Safety is an important issue in mining and one expects that employees are aware of safety issues and comply with safety requirements. The cross-sectional nature of the research had its own limitations. A longitudinal design or mixed-method approach could have revealed stronger causal relations and conclusions. A combination of interviews, observations and repeated surveys over an extended period could have increased the researchers' understanding of these complex relationships.

Furthermore, only a single item measured safety compliance. Although the use of single-item measures is common in psychology, future investigations may look at a broader, multi-item scale to investigate safety compliance.

\section{Recommendations for future research}

Broadly speaking, safety in organisations is a comprehensive phenomenon with variables at the individual, group and organisational levels. Therefore, one should measure them as such (see Zohar, 2010). However, Zohar makes it clear that one should not consider the organisational safety climate, defined as the totality of safety-related issues, as an individual-level phenomenon. Although it may originate at the individual level (with perceptions, experiences and the like), the combined effect is an organisational and group one. Conceptual challenges lie in the temporal aspect. As individual safety perceptions change, they influence the group and the organisation and vice versa (Zohar, 2003).

The current researchers' measures of safety compliance clearly assess individual experiences ('How often do you ignore safety regulations at your workplace?'). Their measures of stress, insecurity, satisfaction and commitment also do so. However, they did not find similar relationships between all independent variables. Methodological issues, like the poor conceptual sophistication of the measure of safety compliance and common method variance may have influenced the results. Further investigations of these relationships seem warranted.

In addition, the findings of this study might show that the individual scales the researchers used, although taken from a strong body of international research, need further refinement and contextualisation for a South African situation. One can also attribute the problems about reliability to the small number of items in each scale.

\section{Recommendations for the organisation and implications for managers}

Clearly, these results present only a first step towards improving our understanding of safety compliance in the mining industry. Nevertheless, the organisation can learn that organisational factors (like work stress and job insecurity) had relationships with safety compliance whilst individual attitudes (commitment and satisfaction) did not. The implication is that managing safety should probably start at an organisational instead of at an individual level and very likely by sensitising managers. 
Other findings suggest that, in order to improve safety, training has to have a specific safety-related focus (Mearns, Hope, Ford \& Tetrick, 2010). This seems to be true for safety transformational leadership as well (Mullen \& Kelloway, 2009). The researchers also showed that job satisfaction plays an important role in safety compliance vs. noncompliance. The literature on job satisfaction is comprehensive and can guide managers to improve it.

Finally, the researchers found that $43 \%$ of employees indicated that they are not always safety compliant. Their responses ranged from 'never' to 'almost always'. Nevertheless, this should be a stark reminder to managers about the importance of safety in mining.

\section{Acknowledgements}

A grant, in terms of the bilateral research agreement between the National Research Foundation South Africa (NRF) and the Swedish International Development Agency (SIDA), partly supported this research (Grant number: 2068671).

\section{Competing interests}

The authors declare that they have no financial or personal relationship(s) that may have inappropriately influenced them in writing this paper.

\section{Authors' contributions}

Uanda Masia completed this research as part of her master's degree in industrial psychology at the Potchefstroom campus of North-West University. She completed most of the literature review and collected the data. Jaco Pienaar conducted the analyses and assisted in interpreting the results.

\section{References}

Adams, D., Du Plessis, A.G., Gumbie, A., \& Willis, R.P.H. (2007). Introduction to safety practice in South African Mines. Braamfontein: Creda Communications.

Allen, N.J., \& Meyer, J.P. (1990). The measurements and antecedents of affective, continuance and normative commitment to the organisation. Journal of Occupational Psychology, 63, 1-8.

Alper, S.J., \& Karsh, B.-T. (2009). A systematic review of safety violations in industry. Accident Analysis and Prevention, 41, 739-754. http://dx.doi.org/10.1016/j. aap.2009.03.013

Ashford, S., Lee, C., \& Bobko, P. (1989). Content, causes and consequences of job insecurity: A theory-based measure and substantive test. Academy of Management Journal, 32, 803-829. http://dx.doi.org/10.2307/256569

Ashworth, S.G.E., \& Peake, A.V. (1994). Assessment of the dominant circumstances and factors giving rise to accidents in the gold and Platinum Mining Industries. Pretoria: SIMRAC.

Barling, J., Loughlin, C., \& Kelloway, E.K. (2002). Development and test of a model linking safety-specific transformational leadership and occupational safety. Journal of Applied Psychology, 87, 488-496. http://dx.doi.org/10.1037/0021 9010.87.3.488, PMid:12090606

Beehr, T.A., Walsh, J.T., \& Taber, T.D. (1976). Relationship of stress to individually and organisationally valued states: Higher order needs as a moderator. Journal of organisationally valued states: Higher order needs as a moderator. Journal of
Applied Psychology, 61, 41-47. http://dx.doi.org/10.1037/0021-9010.61.1.41 Applied Psycholog

Bezuidenhout, A.A. (1992). Die invloed van enkele organisasie-effektiwiteitsdimensies op beroepsveiligheid [The influence of some organisational effectiveness op beroepsveiligheid [The influence of some organisational effectiveness
dimensions on workplace safety]. Unpublished master's dissertation, University dimensions on workplace safety
of South Africa, South Africa.

Brayfield, A.H., \& Rothe, H.F. (1951). An index of job satisfaction. Journal of Applied Psychology, 86, 386-400.

Buitendach, J.H., \& De Witte, H. (2005). Job insecurity, extrinsic and intrinsic job satisfaction and affective organisational commitment of maintenance workers in a parastatal. South African Journal of Business Management, 36(2), 27-37.
Caplan, R.D. (1971). Organizational stress and individual strain: A social psychological study of risk factors in coronary heart disease among administrators, engineers, study of risk factors in coronary heart disease among administrators, engineers,
and scientists (University Microfilms No. 72-14822). Cumulative Progress Report, and scientists (University Microfilms No. 72-14822). Cumulative Progre
Ann Arbor, MI: Institute for Social Research, University of Michigan.

Clarke, S. (2010). An integrative model of safety climate: Linking psychological climate and work attitudes to individual safety outcomes using meta-analysis. Journal of Occupational and Organizational Psychology, 83, 853-578. http://dx.doi. org/10.1348/096317909X452122

Cohen, J. (1988). Statistical power analysis of the behavioural sciences. (rev. edn). Orlando, FL: Academic Press.

Coleman, D.F., Irving, G.P., \& Cooper, C.L. (1999). Another look at the locus of control organisational commitment relationship: It depends on the form of commitment. Journal of Organisational Behavior, 20, 995-1001. http://dx.doi.org/10.1002/ (SICI)1099-1379(199911)20:6<995::AID-JOB955>3.3.CO;2-V

Cooper, C. (1999). What is behaviour safety? Retrieved 22 October 2007, from http:// www. behaviouralsafety.com

Dawson, S. (1991). Managing safety offshore. Offshore Operations Post Piper Alpha. Paper 13. London: Marine Management (Holdings) Ltd.

De Witte, H. (1999). Job insecurity and psychological well-being: Review of the literature and exploration of some unresolved issues. European Journal of Work literature and exploration of some unresolved iss
and Organizational Psychology, 8(2), 155-177.

De Witte, H. (2000). Arbeidsethos en jobonzekerheid: Meting en gevolgen voor welzijn, tevredenheid en inzet op het werk [Work ethics and job insecurity: Assessment and consequences for well-being, satisfaction and performance at work]. In R. Bouwen, K. De Witte, H. De Witte \& T. Tailllieu (Eds.), Van Groep tot gemeenskap [From group to community], (pp. 325-350). Leuven: Garant.

DeFrank, S.R., \& Ivancevich, J.M. (1998). Stress on the job: An executive update. Academy of Management Executive, 12(3), 55-66. http://dx.doi.org/10.5465/ AME.1998.1109050

Dekker, S.W., \& Schaufeli, W.B. (1995). The effects of job insecurity on psychological health and withdrawal: A longitudinal study. Australian Psychology, 30(1), 57103. http://dx.doi.org/10.1080/00050069508259607

Department of Minerals and Energy. (2004). Mine Health and Safety Inspectorate Annual Report. Pretoria: Government printers.

Department of Minerals and Energy. (2008). Mine Health and Safety Inspectorate Annual Report. Pretoria: Government printers.

Dollard, M.F., Winefield, A.H., \& Winefield, H.R. (2003). Occupational stress in the service professions. New York: Taylor \& Francis. http://dx.doi. in the service professions.
org/10.4324/9780203422809

Dunbar, E. (1993). The role of psychological stress and prior experience in the use of personal protective equipment. Journal of Safety Research, 24, 181-187. http:// dx.doi.org/10.1016/0022-4375(93)90029-M

Emberland, J.S., \& Rundmo, T. (2010). Implications of job insecurity perceptions and job insecurity responses for psychological well-being, turnover intentions and risk behavior. Safety Science, 48, 452-459. http://dx.doi.org/10.1016/j. ssci.2009.12.002

Ferguson, J. (2000). Strategies to improve occupational safety at Rietspruit mine Unpublished master's dissertation, Milpark Business School, South Africa.

Fourie, A. (2005). Job insecurity, coping and health-related behaviour. Unpublished master's dissertation, North-West University, Potchefstroom, South Africa.

Fourie, J.S. (1974). Prevention of accidents and the development of a safety programme for open mining and iron ore recasting. Unpublished master's programme for open mining and iron ore recasting.
dissertation, University of South Africa,, South Africa.

Gardner, J.W. (1998). Can change management be successfully implemented at a gold mine to improve safety and productivity? Unpublished master's dissertation, University of Cape Town, Cape Town, South Africa.

Geller, E.S. (1996). Working safe: How to help people actively care for health and safety. Boca Raton: CRC Press LLC.

Gillespie, N.A., Walsh, M., Winefield, A.H., Dua, J., \& Stough, C. (2001). Occupational stress in universities: Staff perceptions of the causes, consequences and moderators of stress. Work and Stress, 15(1), 53- 72.

Greenhalgh, L., \& Rosenblatt, Z. (1984). Job insecurity: Towards conceptual clarity. Academy of Management Review, 9, 438-448. http://dx.doi.org/10.5465/ AMR.1984.4279673

Hellgren, J., Sjöberg, A., \& Sverke, M. (1997). Intention to quit: Effects of job satisfaction and job perceptions. In F. Avallone, J. Arnold \& K. de Witte (Eds.), Feelings work in Europe (pp. 415-423). Milano: Guerini.

Hellgren, J., Sverke, M., \& Isaksson, K. (1999). A two-dimensional approach to job insecurity: Consequences for employee attitudes and well-being. European Journal of Work and Organizational Psychology, 8, 179-195. http://dx.doi. org/10.1080/135943299398311

Hirschfield, R.R. (2000). Validity studies. Does revising the intrinsic and extrinsic subscales of Minnesota Satisfaction Questionnaire Short Form make a difference? Educational Psychology Measurement, 60(2), 255-270.

Hofmann, D.A., \& Stetzer, A. (1998). The role of safety climate and communication in accident interpretation: Implication from negative events. Academy of Management Journal, 41, 644-657. http://dx.doi.org/10.2307/256962

Hofmann, D.A., Jacobs, R., \& Landy, F. (1995). High reliability process industries: Individual, micro, and macro organisational influences on safety performance. Journal of Safety Research, 26, 131-149. http://dx.doi.org/10.1016/00224375(95)00011-E

Ivancevich, J.M., \& Matteson, M.T. (1996). Organisational Behavior and Management. (4th edn.). Boston, MA: Irwin McGraw-Hill. 
Janssens, M.J., Brett, J.M., \& Smith, F.J. (1995). Confirmatory cross-cultural research Testing the viability of a corporation-wide safety policy. Academy of Management Journal, 38, 364-382. http://dx.doi.org/10.2307/256684

Jones, E.E. (1979). The rocky road from acts to dispositions. American Psychologist, 34, 107-117. http://dx.doi.org/10.1037/0003-066X.34.2.107, PMid:484919

Karasek, R.A., \& Theorell, T. (1990). Healthy work: Stress, productivity and reconstruction of working life. New York: Basic Books.

Kendonlin, I. (1993). Burnout of female and male nurses in shift work. Ergonomics, 36, 141-147. http://dx.doi.org/10.1080/00140139308967865, PMid:8440210

Khan, H., \& Cooper, C.L. (1993). Stress in the dealing room. London: Routledge.

Kletz, T.A. (1985). An engineer's view of human error. Warwickshire, England: The Institution of Chemical Engineers.

Kotze, C.G.P. (2005). Occupational stress, organisational commitment and ill health of employees at a University of Technology. Unpublished master's dissertation, Potchefstroom University for Christian Higher Education, Potchefstroom, South Africa.

Kreitner, R., \& Kinicki, A. (2004). Organizational behaviour. (6th edn.). Boston, MA Irwin McGraw-Hill.

Landy, F.J., \& Conte, J.M. (2004). Work in the 21st century. New York: Blackwell.

Larsson, S., Pousette, A., \& Törner, M. (2008). Psychological climate and safety in the construction industry - mediated influence on safety behaviour. Safety Science, 46, 405-412. http://dx.doi.org/10.1016/j.ssci.2007.05.012

Lawrence, A.C. (1974). Human error as a cause of accidents in gold mining. Journal of Safety Research, 6(2), 76-88.

Lim, V.K.G. (1997). Moderating effects of work-based support on the relationship between job insecurity and its consequences. Work and Stress, 11, 251-266.

Marx, C. (1996). An activity-based costing approach to fall of ground accidents in a South African gold mine. Unpublished master's dissertation, Potchefstroom University for Christian Higher Education, Potchefstroom, South Africa.

Matteson, M.T., \& Ivancevich, J.M. (1987). Controlling work stress: Effective human resource and management strategies. San Francisco: Jossey-Bass.

Mearns, K., Hope, L., Ford, M.T., \& Tetrick, L.E. (2010). Investment in workforce health: Exploring the implications for workforce safety climate and commitment. Accident Analysis and Prevention, 42, 1445-1454. http://dx.doi.org/10.1016/j. Accident Analysis

Meyer, J.P., Allen, N.J., \& Smith, C. (1993). Commitment to organisations and occupations: Extensions and test of a three-component conceptualization. Journal of Applied Psychology, 87, 538-551. http://dx.doi.org/10.1037/00219010.78.4.538

Moller, G.P. (2003). The implementation and evaluation of behaviour based safety interventions at Sishen Iron Ore Mine. Unpublished doctoral thesis, Potchefstroom University for Christian Higher Education, Potchefstroom, South Africa.

Monk, T., \& Folkard, S. (1985). Shift work and performance. In S. Folkard \& T. Monk (Eds.), Hours of work, (pp. 239-252). Chichester: Wiley.

Mouton, J., \& Marais, H.C. (1990). Basic concepts in the methodology of socia sciences. Pretoria: Human Sciences Research Council.

Mullen, J.E., \& Kelloway, E.K. (2009). Safety leadership: A longitudinal study of the effects of transformational leadership on safety outcomes. Journal of Occupational and Organizational
org/10.1348/096317908X325313

Näswall, K., Baraldi, S., Richter, A., Hellgren, J., \& Sverke, M. (2006). The salaried employee in the modern working life: Threats and challenges. Technical report omployee in the modern working life: Threats and challenges. Technical report Stockholm, Sweden: SALTSA Joint programme for working life research in Europe.

Neal, A., \& Griffin, M.A. (2006). A study of the lagged relationships among safety climate, safety motivation, safety behavior, and accidents at the individual climate, safety motivation, safety behavior, and accidents at the individual and group levels. Journal of Applied Psychology,

Neal, A., Griffin, M.A., \& Hart, P.M. (2000). The impact of organizational climate on safety climate and individual behaviour. Safety Science, 34, 99-109. http://dx.doi. org/10.1016/S0925-7535(00)00008-4

Nelson, D.L., \& Burke, R.J. (2000). Women executives: Health, stress, and success. Academy of Management Executive, 14(2), 107-121.

Newstrom, J.W., \& Davis, K. (2002). Organisational behaviour: Human behaviour at work. (11th edn.). New York: Mc Graw-Hill.

Nunnally, J.C., \& Bernstein, I.H. (1994). Psychometric theory. (3rd edn.). New York: McGraw-Hill.

Odendaal, E.P.S. (1996). The consequences of poor illumination on underground mine workers and the subsequent effects on productivity and safety. Unpublished doctoral thesis, University of the Witwatersrand, Johannesburg, South Africa.

Pallant, J. (2007). SPSS Survival Manual. (3rd edn.). Berkshire, England: Open University Press.

Paul, P.S., \& Maiti, J. (2005). Development and test of a sociotechnical model for accident/injury occurrences in underground coal mines. Journal of South African institute of Mining and Metallurgy, 105(1), 43-55.

Peng, C.J., Lee, K.L., \& Ingersoll, G.M. (2002). An introduction to Logistic Regression analysis and reporting. Journal of Educational Research, 9(1), 2-13.
Pienaar, J., Sieberhagen, C.J., \& Mostert, K. (2007). Inveatigating turnover intentions by role overload, job satisfaction and social support moderation. SA Journal of Industrial Psychology/SA Tydskrif vir Bedryfsielkunde, 33(2), 62-67.

Probst, T.M., \& Brubaker, T.L. (2001). The effects of job insecurity on employee safety outcomes: Cross-sectional and longitudinal explorations. Journal of Health Psychology, 6(2), 139-159. http://dx.doi.org/10.1037/1076-8998.6.2.139, PMid:11326726

Raath, J.B. (1993). Meeting the safety challenges facing mine managers in a changing South Africa. Leon Commission Report 1(1), 106-112.

Ramakau, J.L. (2006). The relationship between job insecurity, job satisfaction, affective organisational commitment and work locus of control. Unpublished master's dissertation, Potchefstroom University for Christian Higher Education, Vanderbijlpark, South Africa.

Rizzo, J.R., House, R.J., \& Lirtzman, S.I. (1970). Role conflict and ambiguity in complex organizations. Administrative Science Quarterly, 15, 150-163. http://dx.doi. org $/ 10.2307 / 2391486$

Robbins, S.P. (1998). Organisational Behaviour. Upper Saddle River, NJ: Prentice Hal Inc.

Robbins, S.P., Odendaal, A., \& Roodt, G. (2003). Organisational behaviour: Global and Southern African perspective. Pinelands: Pearson Education South Africa.

Rossouw, D., \& Bews, N. (2002). The importance of trust in a changing business environment. Management Today, 18(2), 26-27.

Rothmann, S., \& Malan, M.M. (2006). Occupational stress of engineers in South Africa. Southern African Business Review, 10(2), 1-16.

Republic of South Africa. (1996). Mine Health and Safety Act, 26. Pretoria: GCIS

Republic of South Africa. (1996). Mine Health and Safety Act, no. 29. Pretoria: Government Press.

Rundmo, T., \& Iversen, H. (2007). Is job insecurity a risk factor in occupational health and safety? International Journal of Risk Assessment and Management, 7(2) 165-179. http://dx.doi.org/10.1504/IJRAM.2007.011729

Seccombe, A. (2007). SA mine safety strike to halt output. Retrieved 31 October 2008 from http://www.miningmx.com

Shaughnessy, J.J., \& Zechmeister, E.B. (1997). Research methods in psychology. (4th edn.). New York: McGraw-Hill.

Simpson, G.C., \& Widdas, M. (1992). Reducing the major incident/accident risk. The Mining Engineer, 12(3), 259-265.

Smith, M.J. (1993). Working in the grave: The development of a health and safety system on the Witwatersrand gold mines, 1900 - 1939. Unpublished master's system on the Witwatersrand gold mines, $1900-1939$. Unpt
dissertation, Rhodes University, Grahamstown, South Africa.

Spector, P.E. (1997). Job satisfaction: Application, assessment, causes, and consequences. London: Sage.

SPSS. (2009). SPSS 15.0 for Windows. Chicago, IL: SPSS Incorporated.

Stanton, D.W., Kielblock, J., Schoeman, J.J., \& Johnston, J.R. 2007, Handbook on Mine Occupational Hygiene Measurements. Johannesburg, South Africa: The Mine Occupational Hygiene Measurem
Health and Safety Council (MHSC)

Sverke, M., Hellgren, J., \& Öhrming, J. (1999). Organizational restructuring and health care work: A quasi-experimental study. In P.M. Le Blanc, M.C.W. Peeters, A. Bussing \& W.B. Schaufeli (Eds.), Organisational Psychology and health care: European contributions (pp. 15-32). Munchen: Rainer Hampp Verlag.

The Star. (2007, December 5). Mine Safety is a human right. Retrieved 06 December 2008, from http://www.thestar.co.za

Travers, C.J., \& Cooper, C.L. (1996). Teachers under pressure. Stress in the teaching profession. London: Routledge.

Van Vuuren, T., Klandermans, B., Jacobson, D., \& Hartley, J. (1991). Predicting employees' perceptions of job insecurity. In J. Hartley, D. Jacobson, B. Klandermans \& T. van Vuuren (Eds.), Job insecurity: Coping with jobs at risk, (pp. 65-78). London: Sage Publications.

Van Wyk, E., \& De Villiers, R. (2008). Usability context analysis for virtual reality training in South African mines. Proceedings of the Annual Research Conference of the South African Institute of Computer Scientists and Information Technologists on IT Research in Developing Countries (SAICSIT'08), vol. 338, pp. 276-285, ACM, New York, NY.

Wallace, J.C., Popp, E., \& Mondore, S. (2006). Safety climate as a mediator between foundation climates and occupational accidents: A group-level investigation. Journal of Applied Psychology, 91, 681-688. http://dx.doi.org/10.1037/0021 9010.91.3.681, PMid:16737363

Zohar, D. (1980). Safety climate in industrial organizations: Theoretical and applied implications. Journal of Applied Psychology, 65, 96-102. http://dx.doi. org/10.1037/0021-9010.65.1.96, PMid:7364709

Zohar, D. (2000). A group-level model of safety climate: Testing the effect of group climate on micro-antecedents in manufacturing jobs. Journal of Applied Psychology, 85, 587-596. http://dx.doi.org/10.1037/0021-9010.85.4.587, PMid:10948803

Zohar, D. (2003). Safety climate: Conceptual and measurement issues. In J.C. Quick \& L.E. Tetrick (Eds.), Handbook of occupational health psychology, (pp. 123-142). Washington, DC: American Psychological Association. http://dx.doi. org/10.1037/10474-006

Zohar, D. (2010). Thirty years of safety climate research: Reflections and future directions. Accident Analysis and Prevention, 42, 1517-1522. http://dx.doi. org/10.1016/j.aap.2009.12.019 